\title{
慢性副鼻腔炎症例の嗅覚障害に対する臨床的検討
}

\author{
名古屋市立大学耳鼻咽喉科学教室 \\ 近藤広子高木繁 \\ 三矢 昭治 村上 信五 \\ 名城病院 \\ 杉山 和 子 \\ ペンシルバニア大学 Smell and Taste Center \\ 松田十四
}

\section{CLINICAL ASSESSMENT OF OLFACTORY DISTURBANCE IN CHRONIC SINUSITIS PATIENTS}

\author{
Hiroko Kondo ${ }^{1)}$, Shigeru Takagi'), Shoji Mitsuya'1), \\ Shingo Murakami ${ }^{1)}$, Kazuko Sugiyama ${ }^{2)}$ and Toshi Matsuda ${ }^{2)}$ \\ ${ }^{1)}$ Department of Otolaryngology, Nagoya City University Medical School, Nagoya \\ ${ }^{2}$ Department of Otolaryngology, Meijyo Hospital, Nagoya \\ ${ }^{3}$ Smell and Taste Center, University of Pennsylvania, USA
}

The Cross-Cultural Smell Identification Test (CC-SIT), which was developed as an olfactory test in the United States, has been found useful for clinical assessment of olfactory function in Japan. In this study, thirty-nine chronic sinusitis patients with complaints of olfactory dysfunction were administered three types of olfactory tests: CC-SIT ; a quantified questionnaire about their ability to smell ; and the intravenous olfaction test with Alinamin (Alinamin test), in order to assess the relationship between clinical or X-ray findings and olfactory ability. The closing degree of the olfactory cleft was significantly correlated with the CC-SIT score and the questionnaire score. The opacification degree of the ethmoid sinuses was also significantly correlated with the CC-SIT score and the questionnaire score. The Alinamin test found no relationship between either the closing degree of the olfactory cleft or the opacification degree of the ethmoid sinuses. We concluded that CC-SIT and the questionnaire were more useful to assess olfactory disturbance in chronic sinusitis patients than the Alinamin test.

Key words : 慢性副鼻腔炎, 嗅覚障害, CC-SIT, アリナミンテスト，嗅覚アンケート

1. はじめに

近年嗅覚障害を訴えて，耳鼻咽喉科を訪れる人が増加 しているが，その多くは鼻副鼻腔疾患に起因する。慢性 副鼻腔炎が原因疾患である頻度は高いが，これらの患者 は必ずしも詳細な嗅覚検查を施行されているわけではな い。数多くの嗅覚検査法のうち日本で保険適応があるの は，T＆Tオルファクトメトリー（以下 T \& T法と略）
とアリナミン検査であるが, 前者は換気装置のある特殊 な検査室を必要とし, 検査法も煩雑で日常臨床の合間に は行いにくい。後者は外来で手軽に行えるが，侵襲性の ある検査である。

嗅覚識別検査冊子 Cross- Cultural Smell Identification Test (以下CC-SITと略) は 1980 年代に米 国でDotyらにより開発された検查法で, 12 種の嗅素を用 いて簡便に嗅覚の評価を行える ${ }^{1)} 。$ 
今回我々は嗅覚障害を訴えて受診した慢性副鼻腔炎を 有する患者に対し, CC-SIT, アリナミンテスト，嗅覚ア ンケートの 3 種の嗅覚検査と鼻腔ファイバースコープ及 び副鼻腔画像撮影を施行し, 正常者との比較および臨 床・画像所見と嗅覚の関係について検討した。

\section{2. 対象および方法}

$<$ 対象 $>$

名古屋市立大学病院耳鼻咽喉科を受診した慢性副鼻腔 炎を伴う嗅覚障害症例 39 例（男性 24 名, 平均年歯 47.1 歳，女性 15 名，平均年齢 52.7 歳）と性別・年齢のマッ チングする 39 名の嗅覚正常者(男性 24 名, 平均年齢 47 . 13 歳，女性 15 名，平均年齢 52.2 歳）を対象とした。嗅 覚障害症例には治療開始前に嗅覚テストとして嗅覚アン ケート，CC-SIT，アリナミンテスト（持続時間を測定） を各 1 回ずつ行った。さらにファイバースコープによる 嗅裂の観察, 副鼻腔 $\mathrm{X}$ 線断層または副鼻腔CT冠状断撮影 を施行した。副鼻腔炎以外の原因によるもの，すなわち アレルギー性鼻炎，感冒罹患後，頭部外傷，重度の鼻中 隔弯曲症例などは除外した。正常者例には嗅覚アンケー トとCC-SITを各 1 回ずつ行った。

$<$ 検査方法 $>$

・嗅覚アンケート

生活臭と思われるにおいとして，夕バコ，コーヒー，

表 1 副鼻腔炎症例と嗅覚正常者との比較

\begin{tabular}{c|ccc}
\hline & CC-SIT点数 & アンケート点数 \\
\hline 喚覚正常者 & 9.74 & 29.03 & \\
副皏腔炎症例 & 5.49 & $*$ & $6.49 \quad *$ \\
\hline
\end{tabular}

* ; p $<0.01$ (Mann-Whitney test)
味噌汁, 醬油, 石鹼, 焦げたにおい, 糞尿のにおい, ガ ス，花，果物の 10 項目をあげ，その各々について，わか る 3 ，大体わかる 2 ，殆どわからない 1 ，全くわからな い 0 と点数化（30 点満点）し, 嗅覚の自己評価の指標と した。

- CC-SIT

12 ページからなる冊子で, 各ページに異なった嗅素を マイクロカプセルに詰めたにおい紙があり，そこを鉛筆 でこするとにおいがする。被検者は同じページにある 4 つの選択肢の中から最も近いと思われるにおいを必ず 1 つ選択し，正答数で嗅覚の評価をする。

<嗅裂の閉塞度のスコア化 $>$

嗅覚検査施行時に，ファイバースコープにより，嗅裂 の状態を観察し，両側開通を 0 点，片側開通を 1 点，両 側閉塞を 2 点とスコア化した。さらに副鼻腔断層または 副鼻腔CT冠状断を撮影し, 画像上の咱裂の閉塞度を同様 にスコア化した。

<副鼻腔陰影のスコア化 $>$

篩骨洞，蝶形洞，上顎洞，前頭洞，それぞれ左右別々 に，陰影なしを 0 点，陰影があり腔の $50 \%$ 以下のものを 1 点, $50 \%$ 以上のものを 2 点, $100 \%$ ものを 3 点とスコ ア化し, 左右を合計し， 6 点満点とした。このうち，0〜 1 点のものをグループ $0,2 \sim 3$ 点のものをグループ 1 , $4 \sim 6$ 点のものをグループ 2 とした。

\section{3. 結 果}

表 1 に正常者例と副鼻腔炎症例のCC-SIT点数・アン ケート点数の比較を示す。どちらも正常者例と副鼻腔炎 症例との間に $1 \%$ 危険率で有意差が認められた (Mann-Whitney test)。次にSpearmanの順位相関を用 いて, 嗅裂の閉塞度および副鼻腔陰影と各嗅覚検査との

嗅裂の閉塞度（画像所見） $-S I T$ 点数

嗅裂の閉塞度（画像所見）ーアリナミンテスト

嗅裂の閉塞度（画像所見）ーアンケート点数
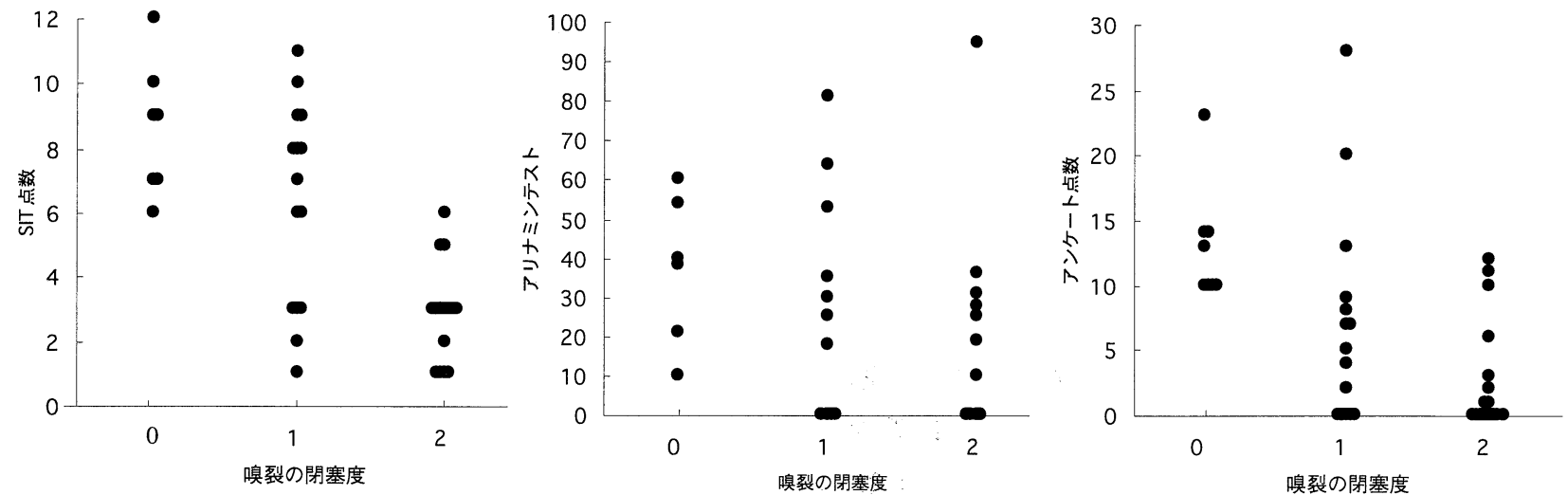

図 1 画像所見による嗅裂の閉塞度と各嗅覚検査との関係 

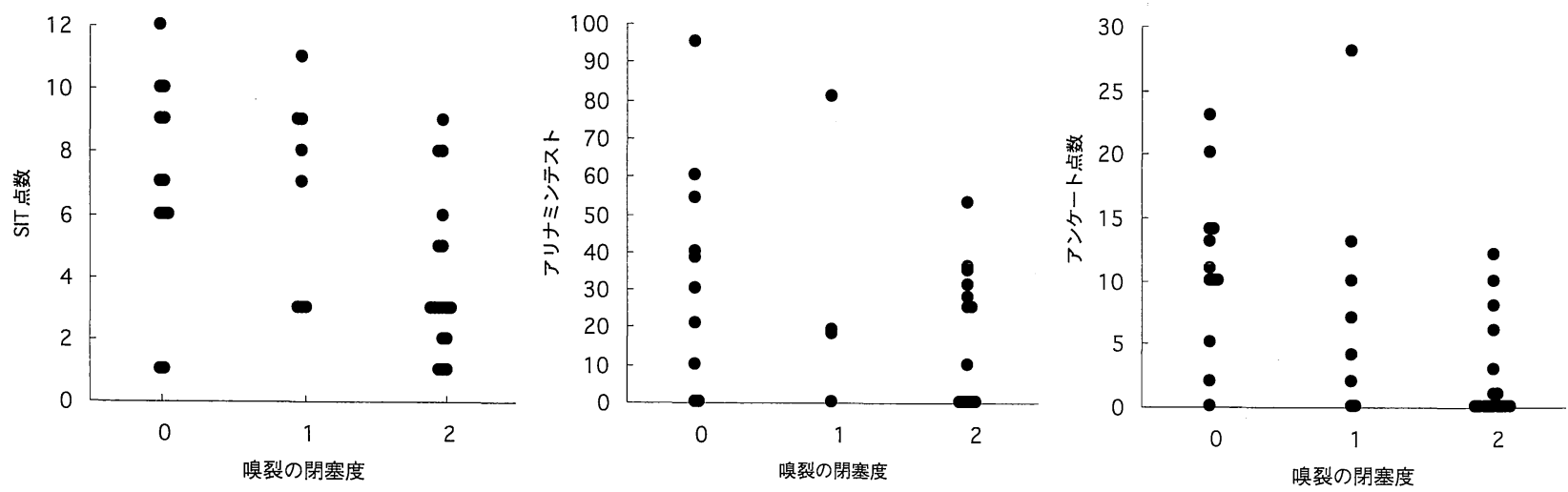

図 2 ファイバー所見による嗅裂の閉塞度と各嗅覚検査との関係

篩骨洞陰影 - SIT 点数

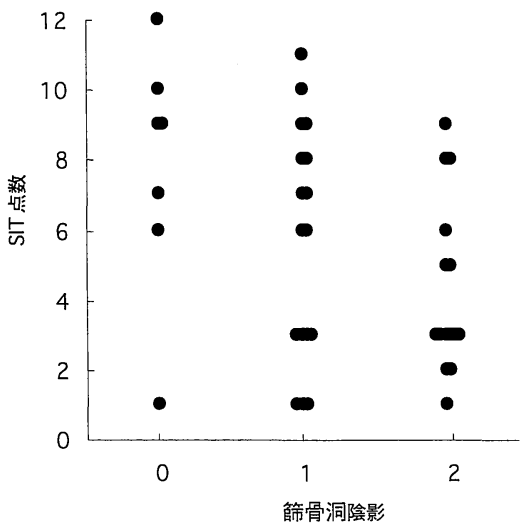

篩骨洞陰影ーアリナミンテスト

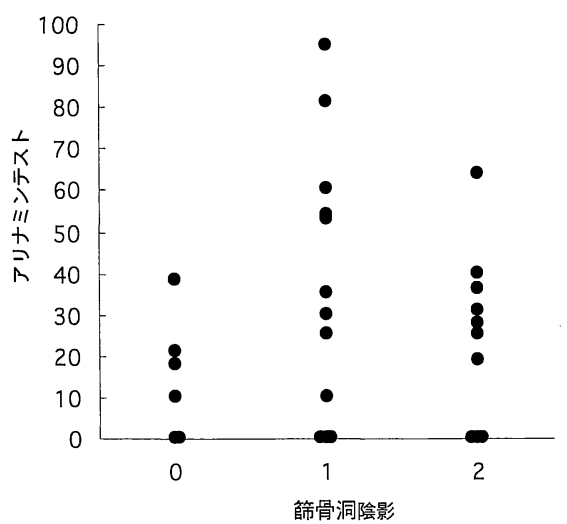

管骨洞陰影
篣骨洞陰影ーアンケート点数

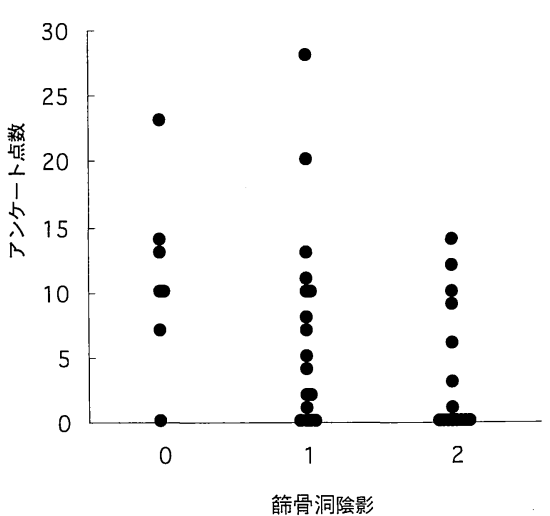

図 3 篩骨洞陰影と各嗅覚検査との関係

相関を調べた。

画像所見による嗅裂の閉塞度と, 各嗅覚検査との関係 を図 1 に示す。嗅裂の閉塞度とCC-SIT点数及びアン ケート点数の間に $1 \%$ の危険率で有意な相関が認められ た $(\rho=0.651,0.546)$ 。

図 2 にファイバー所見による嗅裂の閉塞度と, 各嗅覚 検査との関係を示す。嗅裂の閉塞度とSIT点数及びアン ケート点数の間に $1 \%$ の危険率で有意な相関が認められ た $(\rho=0.429,0.588)$ 。

図 3 に篩骨洞陰影と各嗅覚検査との関係を示す。篩骨 洞陰影とCC-SIT点数及びアンケート点数の間に $5 \%$ の 危険率で有意な相関が認められた（ $\rho=0.350,0.391)$ 。 上顎洞陰影, 前頭洞陰影, 蝶形骨洞陰影と各嗅覚検査 との間には有意な相関は認められなかった（表 2$) 。$

嗅裂の閉塞による影響を除外するため，画像上嗅裂が 閉塞している 16 名を除いて同様の検討を行ったところ， やはり篩骨洞陰影とCC-SIT 点数及びアンケート点数の
表 2 嗅裂の閉塞度および副鼻腔陰影と各嗅覚検査との 関係

\begin{tabular}{|c|c|c|c|}
\hline & アンケート点数 & $\begin{array}{l}\text { アリナミンテスト } \\
\text { 持絸時間（秒） }\end{array}$ & SIT点数 \\
\hline $\begin{array}{c}\text { 嗅裂の閉塞度 } \\
\text { (Fiber所見) }\end{array}$ & $p<0.01$ & NS & $\mathrm{p}<0.01$ \\
\hline $\begin{array}{c}\text { 嗅裂の閉塞度 } \\
\text { (画像所見) }\end{array}$ & $p<0.01$ & NS & $p<0.01$ \\
\hline 篣骨洞陰影 & $p<0.05$ & NS & $p<0.05$ \\
\hline 上䪽洞陰影 & NS & NS & NS \\
\hline 前頭洞陰影 & NS & NS & NS \\
\hline 蝶形洞陰影 & NS & NS & NS \\
\hline
\end{tabular}

間に $5 \%$ の危険率で有意な相関が認められた $(\rho=0.437,0.504)$ 。その他の副鼻腔陰影と各嗅覚検査 
との間には有意な相関は認められなかった。

\section{4. 考 察}

従来日本で施行されてきた嗅覚検査には $\mathrm{T} \& \mathrm{~T}$ 法とア リナミン検査がある。T＆T法は日本で開発された嗅覚 検査であるが2,3)，悪臭の強い嗅素を使用しているため換 気装置のある特別な検査室を必要とし，検査法も煩雑で その施行頻度は低(4)。また閾值の判定が検者によって ばらつく可能性がある5)。アリナミンテストは簡便であ るため日常診療で頻用されているが，侵襲性のある検査 である。T＆ T法，アリナミンテスト共に検查值の測定 が被検者の自己申告に基づくため,客観性に問題がある。 CC-SITは米国で開発された 40 種類の嗅素を用いた嗅 覚検査冊子UPSIT (the University of Pennsylvania Smell Identification Test）を原型とする ${ }^{6,7)}$ 。中国・コロ ンビア・フランス・ドイツ・イタリア・日本・ロシア・ スウェーデンの 8 カ国で調查を行い, UPSITの中で馴染 みがない嗅素を選択・除外し，さらに嗅覚正常者に対し て施行して正答率の良い 12 個の嗅素を選んで作られた ものがCC-SITである1)。非侵襲性の検査法で, 定性検查 ではあるが短時間に簡便に行えるという利点がある。四 者択一方式のため客観性が高く, 日本人の嗅覚検査とし ても有用であるという結果が得られている8,9)。また当教 室が作製した嗅覚アンケートは 10 項目の生活臭につい てに㧈うかどうかを点数方式で答えるものである。被検 者の自己申告式であるため客観性はないが, 種々の嗅覚 検査とある程度相関しており ${ }^{10)}$, 簡便に嗅覚状態を把握 するには有用性が高い。

慢性副鼻腔炎は耳鼻科の日常診療では極めて一般的な 疾患である。嗅覚障害を症状として有する患者も多く, その原因としては呼吸性, 混合性が考えられる。ここで は慢性副鼻腔炎患者に対し短時間に手軽に行える嗅覚検 查法として嗅覚アンケート・CC-SIT・アリナミンテスト を施行した。嗅覚アンケートは患者の自覚症状の指標と して, CC-SIT, アリナミンテストは客観的検查法として 行った。

対象症例と年噛・性別のマッチングした嗅覚正常者と の間では, CC-SIT点数・アンケート点数ともに有意差が 認められ，我々がすでにそれらの有用性を報告してきた ように ${ }^{9)}, \mathrm{CC}-\mathrm{SIT}$ 点数・アンケート点数が慢性副鼻腔炎 の嗅覚障害の判定にも有用であることが裏付けられた。 アリナミンテストについては年齢・性別のマッチングし た正常症例のデー夕がないため同様の検討はできなかっ たが，過去の文献より得られた嗅覚正常者 20 名 (平均年 齢 27 才)の検査結果と比較検討したところ, 今回の対象
症例との間に有意差が認められ; (嗅覚正常者平均 $=169$ 秒, 副鼻腔炎患者平均 $=28$ 秒; $\mathrm{p}<0.01$, Mann-Whitney test）副鼻腔炎患者では持続時間の短縮が認められ た。

慢性副鼻腔炎の嗅覚障害に影響を与える因子として, 嗅裂の閉塞, 副鼻腔炎の重症度が考元られる。そこで嗅 裂の閉塞度および副鼻腔炎の重症度をスコア化し, 各嗅 覚検査との相関について検討した。その結果, 嗅裂の閉 塞度とCC-SIT点数, アンケート点数との間には有意な 相関が認められ，慢性副鼻腔炎患者の嗅覚障害には嗅裂 の開閉が大きく影響していることがうかがわれた。各副 鼻腔の炎症の程度と嗅覚検査との関係を調べてると, 篩骨洞陰影とCC-SIT点数, アンケート点数との間にや はり有意な相関が認められた。嗅裂の閉塞による影響を 除外するため, 嗅裂が両側閉塞している症例を除いて検 討したが，やはり同様の結果が得られた。篩骨洞は嗅裂 に近く篩骨洞の炎症が嗅細胞に波及し, 嗅覚障害を引き 起こしたのではないかと思われる。篩骨洞以外の副鼻腔 の炎症の程度と嗅覚検査の間には相関は認められず, 上 顎洞・蝶形骨洞・前頭洞の炎症は嗅覚化影響を与える可 能性は低いと思われた。一方アリナミンテストは鮕裂の 閉塞度・副鼻腔炎の重症度のどれにも相関が認められな かった。

今回の検討は各検查一度しか行っていないが, 再現性 についてはアリナミンテスト・CC-SIT共に良好である と報告されており ${ }^{11,12,13)}$ ，一度の検査でも信頼性のある 結果が得られていると思われる。

今回は症例数が少ないため引き続き検討が必要であろ うが, 嗅裂の閉塞度・副鼻腔炎の程度と相関の認められ るCC-SITと嗅覚アンケートの方がアリナミンテストよ り慢性副鼻腔炎の嗅覚障害の判定には有用かと思われ た。

\section{5. まとめ}

慢性副鼻腔炎を伴う嗅覚障害症例 39 名に, CC-SIT, アリナミンテスト，嗅覚アンケート，鼻腔ファイバース コープ及び副鼻腔画像撮影を施行し，正常者との比較お よび臨床・画像所見と嗅覚の関係について検討した。 ・CC-SIT点数, 嗅覚アンケート点数は正常者例と副鼻 腔炎症例との間に有意差が認められた。

・嗅裂の閉塞度とCC-SIT点数，アンケート点数との間 に相関が認められた。

・篩骨洞陰影の程度とCC-SIT点数，アンケート点数と の間に相関が認められた。

・アリナミンテストは嗅裂の閉塞度・副鼻腔炎の程度の 


\section{どれにも相関が認められなかった。}

\section{参考文献}

1) Doty RL, Marcus A, Lee WW: Development of the 12-Item Cross-Cultural Smell Identification Test (CC-SIT). Laryngoscope 106: 353-356, 1996.

2 ）豊田文一. 嗅覚検査のための基準臭と検查方式の研 究. 47 年度文部省研究報告集録（医学および薬学 I ) $231-240,1973$.

3 ) 高木貞敬. 嗅覚障害の測定と治療. 豊田文一, 北村 武，高木貞敬編集。医学書院，東京， 1-9, 1978.

4 ) 古田 茂, 大山 勝, 三宅浩郷, 他. 嗅覚検査に関 するアンケート調査成績. 日鼻誌 $32 ： 65,1993$.

5 ）塩川久子：基準臭嗅覚検査に関する基礎的研究一才 ルファクトグラムの作製と嗅覚閾值の年齢的分布 一。日耳鼻 78 : 1258-1270, 1975.

6 ) Doty RL, Shaman P, Dann MS : Development of the University of Pennsylvania Smell Identification Test. Physiology\&Behavior 32 : 489-502, 1984.

7 ) Doty RL, Shaman P, Kimmelnan CP, et al : University of Pennsylvania Smell Identification Test. Laryngoscope 94 : 176-178, 1984.
8 ）古田 茂, 江川雅彦, 大山 勝, 他. 嗅覚識別検査 (Smell Identification Test: Doty) の臨床応用. 日耳鼻 $90 ： 507-515 ， 1987$.

9 ）近藤広子, 松田十四, 羽柴基之, 他：嗅覚検査にお けるSmell Identification Test国際版 (別名CrossCultural Smell Identification Test) の有用性とそ の限界。日鼻誌 36：27-34, 1997.

10) Kondo H, Matsuda T, Hashiba M, et al : A study of the relationship between the $\mathrm{T} \& \mathrm{~T}$ olfactometer and the University of Pennsylvania Smell Identification Test in a Japanese population. Am J Rhinol 12: 353-358, 1998.

11）神尾 鋭：嗅覚検査法，特に静脈性嗅覚検査法に関 する臨床的研究. 日耳鼻 $66: 469-485,1963$.

12）槻陽一郎：経静脈性嗅覚検査に関する臨床的研究. 日耳鼻 $67 ： 1320-1337,1964$.

13) Doty RL, McKeown DA, Lee WW, et al : A study of the test-retest reliability of ten olfactory tests. Chem Senses 20: 645-656, 1995.

(2000 年 1 月 11 日受稿, 2000 年 5 月 19 日受理) 別刷請求先 个467-8601 名古屋市瑞穂区瑞穂町川澄 1 名古屋市立大学医学部耳鼻咽喉科 近藤広子 Tel 052-853-8256 Fax 052-851-5300 